\title{
Scientific contributions of Ibn Hazm
}

\section{Abdi Omar Shuriye* and Femi Salami Abdulazeez}

\author{
Department of Science, \\ Faculty of Engineering, International Islamic, \\ University Malaysia (IIUM), \\ Jalan Gombak, 53100 Kuala Lumpur, Malaysia \\ Fax: +60-3-61964465 \\ E-mail: shuriye@iium.edu.my_E-mail: shuriye@hotmail.com \\ E-mail: abdulazeez.f.salami@ieee.org \\ *Corresponding author
}

\begin{abstract}
The objective of this research is to explore the contributions of Ibn Hazm in science and technology. The research also explains the religious situation, sociopolitical situation, and scientific development during this period. The methodology used is analytical and historical in nature. The significant of the research lies in the fact that it revisits the heritage of Islamic and Arabic contributions to science and technology.
\end{abstract}

Keywords: Ibn Hazm's contributions; Earth's sphericity; geodetic measurements; circumnavigation of the globe; point positioning.

Reference to this paper should be made as follows: Shuriye, A.O. and Abdulazeez, F.S. (2011) 'Scientific contributions of Ibn Hazm', Int. J. Arab Culture, Management and Sustainable Development, Vol. 2, No. 1, pp.30-40.

Biographical notes: Abdi Omar Shuriye is an Associate Professor of contemporary Islamic thought and professional ethics. He obtained his BA, MA and $\mathrm{PhD}$ in Contemporary Islamic Political thought. He has published extensively with international publishers and in international indexed journals in the USA, Malaysia, India, Australia and Europe, in the area of contemporary Islamic political thought and Islamic professional ethics, and presented papers worldwide. His works include: Qur'anic Values in Engineering Studies, Introduction to Political Science: Islamic and Western Perspectives, Legendaries of Islamic Political Thought, Ethics of Engineering Education, Islamic Engineering Ethics, Islamic Ethical Values on Bioengineering Practices: Issues in Genetic Engineering, and Religious and Ethical Worldviews on Engineering Standards. He writes both in English and Arabic. In addition to this, he has also 16 years of teaching experience and held various administrative and academic posts. He currently teaches Islamic professional ethics, political thought, and history Abbasside Caliphate.

Femi Salami Abdulazeez is a Masters of Engineering (Major in Computer and Information Engineering) student at the Department of Electrical and Computer Engineering, International Islamic University Malaysia. He received his Bachelors of Engineering (First Class Honours) from the same university. He is an interdisciplinary thinker who has publications in engineering and has a book on poetry entitled The Monument published by iUniverse. $\mathrm{He}$ has collaboratively worked on professional/governmental projects for the Office of 
the Privacy Commissioner of Canada (OPC) and has acted as a Technical Reviewer for IGI Global, Academy Publisher and other publishing bodies. $\mathrm{He}$ is a member of IEEE (Institute of Electrical and Electronics Engineering) Communications Society.

\section{Introduction}

This research consists of two parts. In the first part the research covers Ibn Hazm's contributions in general, his works, scholars who wrote on him, translations of Ibn Hazm's works in different languages, his contributions to the classification of science, and his contributions to natural sciences. In part two, the research explores the discovery of the Earth's sphericity as Ibn Hazm's main contribution to science. This part therefore studies the historical development of the Earth's sphericity, conceptual definition of the Earth's sphericity, and the importance of Ibn Hazm's contribution to circumnavigation of the globe. The research further investigates Ibn Hazm's contribution to geodetic measurements, his contribution to point positioning and his contributions to radius and models of the Earth.

\section{Biographical sketch, religious situation and sociopolitical situations}

Abu Muhammad Ali Ibn Ahmad Ibn Sa'id Ibn Hazm was born in November 7, 994 and died in August 15, 1064 (Arberry, 1997). The Ibn Hazm family came from Cordoba, a city in southern Spain and the centre of Moorish culture (Al-Hassani and Zaimeche, 2003a). The great-grandfather of Ibn Hazm was converted to Islam from Christianity (Daniel, 1975a). Ibn Hazm's father who is Abu Umar Ahmad Ibn Sa'id Ibn Hazm (d. 1012) held the position of vizier (now known as Minister) at the court of Ummayad Caliph Hashim II (also known as Al-Mansur) (Daniel, 1993).

Al-Mansur's reign was one of the greatest moments of Islamic Spanish history. Al-Mansur had led Muslim armies into victories of unprecedented scale against their Christian foes. Upon the death of Al-Mansur, the Islamic Empire was faced with intrigues, divisions, and conflicts between numerous factions and the once most powerful state collapsed into chaos, and was never to recover (Hillenbrand, 1999).

Christian armies were aware and part of this and they seized their chance to carve up the Islamic dominion. The Christian armies gradually achieved this on two occasions. Firstly, during the Almoravid and secondly, during the Almohad intrusions, which slowed the Christian advance by about two centuries (Gabrielli, 1957). Early in the 13th, after the final defeat of the Almohads, Cordova, Valencia, Seville, and other Islamic strongholds all fell. Granada alone was to remain Muslim, until, it too, ridden with intrigues and disunity, finally fell in 1492. The Muslims were to be eliminated completely from Spanish soil not long after (Al-Hassani and Zaimeche, 2003a).

Ibn Hazm lived among the circle of the ruling aristocracy of the Umayyad Government. Together with his excellent education at Cordoba, this experience gave him an eager, inquisitive and observant attitude (Encyclopedia Brittanica, 2006). As a result of his talent, he earned fame and served the Caliphs of Cordoba. Most especially, he was 
known to have worked under Al-Mansur Ibn Abi Aamir, Hajib (Grand Vizier) to the last of the Ummayad caliphs, Hisham III (Iqbal, 2000).

After the death of the Grand Vizier Al-Muzaffar in 1008, the Umayyad Caliphate of Spain became involved in a bloody civil war that lasted until 1031 resulting in the collapse of the central authority of Cordoba. Ibn Hazm's father died in 1012, however Ibn Hazm continued to speak in favour of a centralised Islamic political structure which resulted in him being accused of supporting the Umayyads and as a result of this, Ibn Hazm was unfortunately, frequently imprisoned (Daniel, 1993).

\section{Ibn Hazm's general contributions to scientific development}

As a result of the sociopolitical instability of the period, Ibn Hazm retreated to his family estate at Manta Lisham in the year 1031 and from there he produced a huge number of significant scientific and literary works (Encyclopedia Brittanica, 2006). According to one of his sons, Ibn Hazm produced 80,000 pages of writing which consists of 400 works but only 40 of those works are currently in existent. Ibn Hazm's literary work covers a diverse and impressive range of topics, namely; anthropology, jurisprudence, science, logic, history, ethics, comparative religion and theology (Al-Hassani and Zaimeche, 2003). He is also fond of adventures and travels. Consequently, he wrote about his visit to the island of Majorca and its capital Medina Mayurqa near Palma and he gave an interesting and beneficial insight into the invention and construction of Caravels (Coles, 1968a).

The life and thoughts of Ibn Hazm are good illustration and product of the chaos and collapse of the Islamic Empire. This collapse and political unrest had direct impact on Ibn Hazm who was at the centre stage of events which made him a victim of unfortunate circumstances for certain periods of his life (Daniel, 1975b). He held positions of power and prestige followed by demise and disgrace as a result of the political fortunes and misfortunes of his patrons. The upheavals of political career also accounts for his withdrawal from public life and devoting himself to study, teaching and writing (Islamic Philosophy Online, 2007). Conclusively, Ibn Hazm is a famous, revered and well-respected Islamic scholar and according to a saying of his period, "the tongue of Ibn Hazm was a twin brother to the sword of al-Hajjaj (a famous 7th century general and governor of Iraq)" (Al-Hassani and Zaimeche, 2003a).

Ibn Hazm's vast and versatile erudition enabled him to extend his thinking to diverse areas of science. Therefore, in order to conduct a comprehensive study on his contributions, one has to be aware of the issues which Muslim thinkers have addressed (Al-Hassani and Zaimeche, 2003a): Apart from his scientific contributions, he was also revered as one of the most original theologians and literati of Muslim Spain and a master of reputable disciplines such as law, history, grammar, poetry, genealogy and logic (Draper, 1875).

According to two of the main Muslim biographers (Yaqut and Al-Qifti), Ibn Hazm has written nearly four hundred (400) works. This approximately amounts to 80,000 pages. A list of his surviving works is given below (Scheindlin, 1998):

- Maratib al-Ulum (The Categories of the Sciences)

- Ihkam al-Ihkam fi usul al-Ahkam (Perfect Knowledge of the Foundations of Jurispudence) 
- Kitab Jamharat al-Arab (On the Arab Genealogy)

- Risala fi fadl al-Andalus wa dikr rijaliha (A Letter on the Merits of al-Andalus and the Memory of its Men)

- Kitab al-Akhlak wa'l siyar (The Book of Morals and Behavior)

Ibn Hazm is mentioned in a number of Arabic sources and some of these sources are given below (Al-Hassani and Zaimeche, 2003a, 2003b):

- Al-Dabbi: Bughyat al-Multamis, Madrid, 1885.

- Hajji Khalifa: Kesf al-zounoun, edt. Constantinople, 1941.

- Ibn Bashkuwal: Kitab as-Sila, Madrid, 1882-3.

- Ibn Khallikan: Wafayat al-a'yan, Cairo, 1275 AH.

- Ibn Qasim ibn Said: Tabaqqat al-Umam, edited by L. Cheiko, Beyrouth, 1902.

- Al-Maqqari: Analectes, Leyde, 1855-61.

- Al-Marrakushi: Histoire des Almohades, Trad. Fagnan, Algiers, 1893.

- Yaqut al-Hamawi: Mo’jam al-Oddaba, edt. Rifai Bey, Cairo, Vol. 12.

Nowadays, the works of Ibn Hazm is comparatively lesser among English sources. A good entry on Ibn Hazm is in the Enclyclopedia of Islam by Arnandez which was written in French. However, there is a main work of Ibn Hazm which has gained the interest and attention of English-speaking scholars and this is Tawq al-Hamama. This work was translated by A.J. Arbery in London, 1953 (Al-Hassani and Zaimeche, 2003b).

Ibn Hazm's thoughts and philosophy on science have also another dimension. Customarily, Islamic scholars like Al-Ghazali classify sciences in order to provide some sort of division that helps in their understanding, study and promotion. This classification has gradually led to our modern learning system in departments, faculties, and courses. Prior to the Muslim classifications, sciences were a bulk of knowledge just like a precious stone mingled with rough metals and Earth (Bennett, 1992). Therefore, there were no distinct boundaries and it was easy to find a chemist dabbling into the field of a magician or a philosopher. It was extremely difficult to stop the non-scientific scholars from taking over the scientific fields. Hence, science was stagnated and diverted into inappropriate directions before the classification of science by Muslim scholars (Daniel, 1993).

Ibn Hazm made a unique contribution to the classification of sciences by providing the boundaries and the rules within science as a whole. Moreover, he made an important contribution by providing the seeker of science indications of how to go on about it. $\mathrm{He}$ accomplished this by classifying and clarifying the highly complex, abstract, moral and down-to-Earth topics such as the prudent conduct in scientific gatherings (Draper, 1875).

\section{Ibn Hazm's contributions to natural sciences}

In addition to his vast contributions to Philosophy, Religious Dialogue, Jurisprudence, Literature, Theory of Knowledge and Social Sciences, Ibn Hazm made significant 
contributions to Natural Sciences (Al-Hassani and Zaimeche, 2003b). His contributions are scattered throughout his books and it needs to be collected together in a cohesive manner. However, some of his contributions to Natural Science can be found in his:

1 Al-Taqreeb

2 Al-Fassl Fil Milal

3 response to Al-Razi (objecting to his views on the origin of the universe) (Scheindlin, 1998).

Ibn Hazm attributed special significance to the number 1 . He claimed that 1 is not a number because there is no other number like it. He further supported his claim by saying that if you split 1, it becomes a fraction. Hence, it will lose its oneness (Draper, 1875). In the area of geometry, he defines the line as the ultimate edge of any surface and a point as the crossing between two lines. He also made scholarly remarks on the concept of infinity and the finite. He referred to the universe as limited and bounded because it was created and made of limited parts. He also referred to the present objects, living creatures and plants as limited while the ones which have not yet been created (such as humans who are not yet born) as unlimited (Al-Hassani and Zaimeche, 2003b).

A very interesting notion on the nature of motion of bodies is found in his work. He explained that there are mobile objects and stationary objects but there is neither motion nor stationariness. Ibn Hazm refuted astrologers who believed that stars and planets have souls and minds and can influence people (Daniel, 1993). He maintained that stars are celestial bodies with no mind or soul with no knowledge of the future and with no power to affect people. He further mentioned that there effect on people is through their physical characteristics just like the effect of the sun's heat and rays on the planets and the effect of the moon on the tides of seas. He explained that Saturn's orbit takes 33 years. Today's astronomy recognises Saturn's orbit around the sun (not the Earth) taking 29 years (Encyclopedia Brittanica, 2006).

He argued against those who believe that the sun sets in one of the seas on Earth. He questions the possibility of a larger sun setting in a smaller Earth. He claimed that the Earth is spherical despite what is popularly believed. He proved this by explaining that the sun is always vertical to a particular spot on Earth. Ibn Hazm considered shooting stars to be hot fires that conglomerate into stars which eventually lose their light by burning. He challenged all theories on the age of the Earth. He argued that Muslims do not have definite knowledge of the age of the Earth and he concluded that it could be many multiples of the ages suggested by others (Coles, 1968b).

Ibn Hazm made similar discoveries to his contemporary Al-Hasan Ibn Al-Haytham (b. 965-1039). They proved that light is reflected from the object and passes through the eye which is a spherical hollow ball that has a sensitive inner service that detects the light (image). They proved that the angle of incidence equals the angle of reflection and they constructed a dark box with one pin hole on its side (called it camara-camera) to prove this theory (Al-Hassani and Zaimeche, 2003b).

Ibn Hazm's view on sound is that it travels at specific speeds. He gave examples to prove this. Such examples include reference to the interval between lightening and the thunder that follows it. In this, he implicitly believes that lightening causes thunder. Ibn Hazm expressed views on the development of life and species. He classified them into 
categories according to the process of their inception and development. He went into the details of various insects (such as lice and flies) and animals (such as frogs) (Daniel, 1975b).

\section{Ibn Hazm's main contribution to science: the discovery of the Earth' sphericity}

Eminent Muslim mathematicians formulated a special trigonometry for the measurement and calculation of the distance and direction of any given point on the Earth to Mecca. This was used to determine the direction of prayer (Qibla) for Muslims (King, 1993).

Around $830 \mathrm{AD}$, Caliph Al-Mamun delegated some Muslim astronomers and geographers to measure the distance from Tadmur (Palmyra) to al-Raqqah in modern Syria. The cities were found to be separated by one degree of latitude and the distance between them was investigated to be $662 / 3$ miles. Therefore, they calculated the Earth's circumference to be 24,000 miles (Gharā'ib). An estimate given by Al-Mamun's other astronomers were $562 / 3$ Arabic miles per degree. This represents $111.8 \mathrm{~km}$ per degree and a circumference of $40,248 \mathrm{~km}$ which is very close to the modern values of $111.3 \mathrm{~km}$ per degree and 40,068 km circumference, respectively (Kennedy, 1996).

A 9th century Persian astronomer by the name Al-Farghani was also commissioned by Al-Mamun to measure the diameter of the Earth. He estimated a degree to be $562 / 3$ Arabic miles. This was more highly accurate than the 60 2/3 Roman miles $(89.7 \mathrm{~km})$ given by Ptolemy (Fernández-Armesto, 1974). A new method for accurately computing the circumference of the Earth was used by Al-Biruni in which he gave a value of 6,339.9 $\mathrm{km}$ as the radius of the Earth. This was merely $16.8 \mathrm{~km}$ less than the modern estimate of $6,356.7 \mathrm{~km}$ (Aber, 2003). This idea was discovered when he was on top of a tall mountain. He sighted the angle to the horizon from the top of the mountain and by also knowing the height of the mountain; he was able to calculate the curvature of the Earth (Mercier, 1992).

The Earth's shape can be described as an oblate spheroid. This is a sphere whose axis from pole to pole is flattened such that there is a bulge around the equator. The reason for this bulge is the Earth's rotation (Milbert and Smith, 1996). The pole to pole diameter will resultantly be $43 \mathrm{~km}$ lesser than the diameter of the equator. An average diameter of about $12,742 \mathrm{~km}$ was estimated for the reference spheroid. This is roughly $40,000 \mathrm{~km} / \pi$ because the meter was first defined as $1 / 10,000,000$ of the distance from the equator to the North Pole through Paris (Sandwell and Smith, 2006).

Local topography differs from this ideal spheroid but these deviations are very small on a global scale. Earth has a tolerance of about one part in about 584 , or $0.17 \%$, from the reference spheroid, which is less than the $0.22 \%$ tolerance allowed in billiard balls (Mohr and Taylor, 2000). The largest local deviations in the rocky surface of the Earth are Mount Everest $(8,848 \mathrm{~m}$ above local sea level) and the Mariana Trench $(10,911 \mathrm{~m}$ below local sea level). Due to the equatorial bulge, the surface locations farthest from the centre of the Earth are the summits of Mount Chimborazo in Ecuador and Huascaran in Peru (http://www.abc.net.au/science/k2/moments/s1086384.htm).

He claimed that the Earth is spherical despite what is popularly believed. He proved this by explaining that the sun is always vertical to a particular spot on Earth (Al-Hassani and Zaimeche, 2003a, 2003b). The explanation for this is that approximately half of the Earth is illuminated at any given time by sunlight. The area subjected to direct 
illumination is almost exactly half the planet; but because of atmospheric and other effects that extend the reach of indirect illumination, the area of the planet covered by either direct or indirect illumination amounts to slightly more than half the surface (Glick et al., 2005).

The hemisphere of the Earth experiencing daytime at any given instant changes continuously as the planet rotates on its own axis. The axis of the Earth's rotation is not exactly perpendicular to the plane of its orbit around the sun and so the length of the daytime period varies from one point on the planet to another (Hugh Thurston). Moreover, since the axis of rotation is relatively fixed in comparison to the stars, it moves with respect to the sun as the planet orbits the star. This creates seasonal variations in the length of the daytime period at most points on the planet's surface (Glick et al., 2005).

The period of daytime is roughly defined as the period between sunrise when the Earth's rotation towards the east first causes the sun's disc to appear above the horizon to sunset when the continuing rotation of the Earth causes the sun's disc to disappear below the horizon to the west (King, 1993). Furthermore, the Earth's atmosphere further diffuses light from the sun and lengthens the period of sunrise and sunset. For a certain period after sunset and before sunrise, indirect light from the sun lightens the sky on Earth; this period is often referred to as twilight (Sarma, 2008).

The first direct demonstration of Earth's sphericity came in the form of the first circumnavigation in history, an expedition captained by Portuguese explorer Ferdinand Magellan. The expedition was financed by the Spanish Crown. On August 10, 1519, the five ships under Magellan's command departed from Seville. They crossed the Atlantic Ocean, passed through the Strait of Magellan, crossed the Pacific, and arrived in Cebu, where Magellan was killed by Philippine natives in a battle. His second in command, the Spaniard Juan Sebastián Elcano, continued the expedition and, on September 6, 1522, arrived at Seville, completing the circumnavigation. Charles I of Spain, in recognition of his feat, gave Elcano a coat of arms with the motto Primus circumdedisti me (in Latin, "You went around me first") (Nowell, 1962).

A circumnavigation alone does not prove that the Earth is spherical. It could be cylindric or irregularly globular or one of many other shapes. Still, combined with trigonometric evidence of the form used by Eratosthenes 1,700 years prior, the Magellan expedition removed any reasonable doubt in educated circles in Europe (Jacobs, 2006).

The level is used for determining height differences and height reference systems, commonly referred to mean sea level. The traditional spirit level produces these practically most useful heights above sea level directly; the more economical use of GPS instruments for height determination requires precise knowledge of the figure of the geoid, as GPS only gives heights above the GRS80 reference ellipsoid. As geoid knowledge accumulates, one may expect use of GPS heighting to spread (Hofmann-Wellenhof and Moritz, 2005).

The theodolite is used to measure horizontal and vertical angles to target points. These angles are referred to the local vertical. The tachometer additionally determines, electronically or electro-optically, the distance to target, and is highly automated to even robotic in its operations. The method of free station position is widely used (Meyer et al., 2007).

For local detail surveys, tachometers are commonly employed although the old-fashioned rectangular technique using angle prism and steel tape is still an inexpensive alternative. Real-time kinematic GPS techniques are used as well. Data 
collected are tagged and recorded digitally for entry into a Geographic Information System database (Vaníček and Krakiwsky, 1986).

Geodetic GPS receivers produce directly three-dimensional coordinates in a geocentric coordinate frame. Such a frame is, e.g., WGS84, or the frames that are regularly produced and published by the International Earth Rotation and Reference Systems Service. GPS receivers have almost completely replaced terrestrial instruments for large-scale base network surveys. For Planet-wide geodetic surveys, previously impossible, we can still mention Satellite Laser Ranging and Lunar Laser Ranging and Very Long Baseline Interferometry techniques. All these techniques also serve to monitor Earth rotation irregularities as well as plate tectonic motions (Hofmann-Wellenhof and Moritz, 2005).

Gravity is measured using gravimeters. Basically, there are two kinds of gravimeters. Absolute gravimeters, which nowadays can also be used in the field, are based directly on measuring the acceleration of free fall. They are used for establishing the vertical geospatial control. Most common relative gravimeters are spring-based. They are used in gravity surveys over large areas for establishing the figure of the geoid over these areas. Most accurate relative gravimeters are superconducting gravimeters, and these are sensitive to one thousandth of one billionth of the Earth surface gravity. Twenty-some superconducting gravimeters are used worldwide for studying Earth tides, rotation, interior, and ocean and atmospheric loading, as well as for verifying the Newtonian constant of gravitation (Hofmann-Wellenhof and Moritz, 2005).

Point positioning is the determination of the coordinates of a point on land, at sea, or in space with respect to a coordinate system. Point position is solved by computation from measurements linking the known positions of terrestrial or extraterrestrial points with the unknown terrestrial position. This may involve transformations between or among astronomical and terrestrial coordinate systems (Jacobs, 2006).

The known points used for point positioning can be triangulation points of a higher order network, or GPS satellites. Traditionally, a hierarchy of networks has been built to allow point positioning within a country. Highest in the hierarchy were triangulation networks. These were densified into networks of traverses, into which local mapping surveying measurements, usually with measuring tape, corner prism and the familiar red and white poles, are tied (Vaníček and Krakiwsky, 1986).

Nowadays, all but special measurements are performed with GPS. The higher order networks are measured with static GPS, using differential measurement to determine vectors between terrestrial points. These vectors are then adjusted in traditional network fashion. A global polyhedron of permanently operating GPS stations under the auspices of the IERS is used to define a single global, geocentric reference frame which serves as the 'zero order' global reference to which national measurements are attached (Meyer et al., $\mathrm{xxxx}$ ).

For surveying mappings, frequently Real Time Kinematic GPS is employed, tying in the unknown points with known terrestrial points close by in real time. One purpose of point positioning is the provision of known points for mapping measurements, also known as control. In every country, thousands of such known points exist and are normally documented by the national mapping agencies. Surveyors involved in real estate and insurance will use these to tie their local measurements to (Hofmann-Wellenhof and Moritz, 2005).

Earth's rotation, internal density variations, and external tidal forces cause it to deviate systematically from a perfect sphere. Local topography increases the variance, 
resulting in a surface of unlimited complexity. Our descriptions of the Earth's surface must be simpler than reality in order to be tractable. Hence, we create models to approximate the Earth's surface, generally relying on the simplest model that suits the need (Vaníček and Krakiwsky, 1986).

Each of the models in common use comes with some notion of 'radius'. Spheres are the only solids to have radii, but looser uses of the term 'radius' are common in many fields, including those dealing with models of the Earth. Viewing models of the Earth from less to more approximate:

1 the real surface of the Earth

2 the geoid, defined by mean sea level at each point on the real surface

3 an ellipsoid: geocentric to model the entire Earth, or else geodetic for regional work

4 a sphere (Moritz, 1980).

In the case of the geoid and ellipsoids, the fixed distance from any point on the model to the specified centre is called 'a radius of the Earth' or 'the radius of the Earth at that point'. It is also common to refer to any mean radius of a spherical model as 'the radius of the Earth'. On the Earth's real surface, on other hand, it is uncommon to refer to a 'radius', since there is no practical need. Rather, elevation above or below sea level is useful (Hofmann-Wellenhof and Moritz, 2005).

Regardless of model, any radius falls between the polar minimum of about $6,357 \mathrm{~km}$ and the equatorial maximum of about $6,378 \mathrm{~km}$. Hence, the Earth deviates from a perfect sphere by only a third of a percent, sufficiently close to treat it as a sphere in many contexts and justifying the term 'the radius of the Earth'. While specific values differ, the concepts in this article generalise to any major planet (Meyer et al., 2007).

\section{Conclusions}

Much of Ibn Hazm's work is still in Arabic. Although there are numerous Spanish and French translations of some of his books, there are very few in English. This project explained his contributions and thought on science, its virtues, territoriality, methods of its instruction and acquisition. Ibn Hazm's status is comparable to the French philosopher-rationalist, Descartes. Perhaps more appropriately, comparisons should have been drawn between Ibn Hazm and the other French philosopher-scientist: Pascal: the cohabitation, or the working together of science and high, God-inspired morality.

Ibn Hazm's thoughts and philosophy on science have also another dimension. He immensely helped in classifying sciences in order to foster their understanding and promotion. He drew the boundaries and rules within science as a whole. This classification has gradually perfected our modern learning system. Any scholar who is often at odds with themselves and the how's and why's of their science have to return to Ibn Hazm. He has made substantial contribution to the clarification of scientific thought. 


\section{References}

Aus. Broad. Corp., Tall Tales about Highest Peaks, pp.1-3, available at $\mathrm{http}: / /$ www.abc.net.au/science/k2/moments/s1086384.htm (accessed on 10/14/2010).

Aber, J.S. (2003) 'Alberuni calculated the Earth's circumference at a small town of Pind adan Khan, District Jhelum, Punjab, Pakistan', Abu Rayhan al-Biruni, pp.1-7, Emporia State University, Kansas, USA.

Al-Hassani, S. and Zaimeche, S. (2003a) Ibn Hazm's Philosophy and Thoughts on Science, November, pp.2-8, FSTC Limited.

Al-Hassani, S. and Zaimeche, S. (2003b) Ibn Hazm's Philosophy and Thoughts on Science, November, pp.4-9, FSTC Limited.

Arberry, A.J. (1997) The Ring of Dove: A Treatise on the Art and Practice of Arab Love, Ibn Hazm, ISBN 1-898942-02-1, pp.1-5, Luzac Oriental, London.

Bennett, A. (1992) Victorian Images of Islam, pp.140-145, Grey Seal, London.

Coles, P. (1968a) The Ottoman Impact on Europe, pp.70-77, Thames and Hudson, London.

Coles, P. (1968b) The Ottoman Impact on Europe, pp.75-81, Thames and Hudson, London.

Daniel, N. (1975a) The Arabs and Medieval Europe, pp.10-13, Longman Librarie du Liban, London.

Daniel, N. (1975b) The Arabs and Medieval Europe, pp.300-305, Longman Librarie du Liban, London.

Daniel, N. (1993) Islam and the West, pp.21-23, Oneworld, Oxford.

Draper, J.W. (1875) A History of the Intellectual Development of Europe, Revised ed., Vol. 1, pp.284-291, George Bell and Sons, London.

Encyclopedia Brittanica (2006) Ibn Hazm, 23 October, pp.1-3.

Fernández-Armesto, F. (1974) Columbus and the Conquest of the Impossible, pp.20-21, Phoenix Press, New York, USA.

Gabrielli, F. (1957) Arab Historians of the Crusades, pp.15-23, Routledge, London.

Glick, T.F., Livesey, S.J. and Wallis, F. (Eds.) (2005) Medieval Science, Technology, and Medicine: An Encyclopedia, ISBN0-415-96930-1, pp.252-374, Routledge, New York.

Hillenbrand, C. (1999) The Crusades: Islamic Perspectives, p.13, Edinburgh University Press, Edinburgh, UK.

Hofmann-Wellenhof, B. and Moritz, H. (2005) Physical Geodesy, pp.171-303, Springer-Verlag, Wien, (This text is an updated edition of the 1967 classic by Heiskanen, W.A. and Moritz, H.).

Ibn Hazm (1903) Kitab al-fisal fi'l-milal wa-l-ahwa wa-l-nihal, 5 parts in two vols; Cairo, 1899 Vol. 1, p.72.

Iqbal, M. (2000) The Reconstruction of Religious Thought in Islam, Kitab Bhavan, ISBN 81-7151-081-7, Chapter 5, pp.1-3.

Islamic Philosophy Online (2007) Ibn Hazm, 4 December, pp.1-5.

Jacobs, J. (2006) The Story of Geographical Discovery, p.90, General Books LLC, Memphis, Tennessee, USA.

Kennedy, E.S. (1996) Mathematical Geography, edited by Rashed, R. and Morelon, R. pp.185-201, American University of Beirut Publisher, Lebanon.

King, D.A. (1993) Astronomy in the Service of Islam, pp.119-123, Variorum, UK.

Mercier, R.P. (1992) 'Geodesy', in Harley, J.B. and Woodward, D. (Eds.): The History of Cartography, Vol. 2.1, pp.182-184, , ISBN 978-0-226-31635-2, Cartography in the Traditional Islamic and South Asian Societies, University of Chicago Press, Chicago and London. 
Meyer, T.H., Roman, D.R. and Zilkoski, D.B. (2007) 'What does height really mean?', This is a series of four articles published in Surveying and Land Information Science, SaLIS, pp.223-233, University of Connecticut Press, Connecticut, USA.

Milbert, D.G. and Smith, D.A. (1996) 'Converting GPS height into NAVD88 elevation with the GEOID96 geoid height model', National Geodetic Survey, NOAA, pp.219-236, American Congress on Survey and Mapping Press, Washington, USA.

Mohr, P.J. and Taylor, B.N. (2000) 'Unit of length (meter)', NIST Reference on Constants, Units, and Uncertainty, NIST Physics Laboratory, October, p.11, available at http://www.physics.nist.gov/cuu/Units/meter.html (accessed on 10/08/2010).

Moritz, H. (1980) Geodetic reference system 1980, by resolution of the XVII General Assembly of the IUGG in Canberra, pp.388-398.

Nowell, C.E. (Ed.) (1962) Magellan's Voyage around the World: Three Contemporary Accounts, pp.269-341, NU Press, Evanston.

Sandwell, D.T. and Smith, W.H.F. (2006) Exploring the Ocean Basins with Satellite Altimeter Data, 7 July, pp.1-4, NOAA/NGDC, available at http://www.ngdc.noaa.gov/mgg/bathymetry/predicted/explore.html (accessed on 10/06/2010).

Sarma, K.V. (2008) Encyclopaedia of the History of Science, Technology, and Medicine in Non-Western Cultures, 2nd ed., edited by Selin, H., ISBN 9781402045592, pp.603-768, Springer Verlag, London.

Scheindlin, R.P. (1998) 'Ibn Hazm (384-456/994-1064)', in Meisami, J.S. and Starkey, P. (Eds.): Encyclopedia of Arabic Literature, p.333, Routledge, London.

Vaníček, P. and Krakiwsky, E.J. (1986) Geodesy: the Concepts, p.714, Elsevier, North Holland, Amsterdam. 